\title{
THE ROLE OF PERCEIVED ORGANIZATIONAL SUPPORT IN SUPPORTING LOCAL GOVERNMENTS' TAX APPARATUS TO OPTIMIZE LOCAL TAX REVENUE
}

\begin{tabular}{|c|c|}
\hline \multicolumn{2}{|c|}{$\begin{array}{c}\text { Puti Nurul Karimah }{ }^{1} \text {, Fauzan Misra }{ }^{2} \\
\text { Universitas Andalas, Padang - Indonesia }\end{array}$} \\
\hline INFO ARTIKEL & ABSTRAK/ABSTRACT \\
\hline $\begin{array}{l}\text { Histori Artikel : } \\
\text { Tgl. Masuk : 11-02-2020 } \\
\text { Tgl. Diterima : 01-03-2020 } \\
\text { Tersedia Online : 20-04-2020 } \\
\text { Keywords: } \\
\text { Perceived } \\
\text { Organizational Support, } \\
\text { Quality, Tax Apparatus, } \\
\text { Optimalization, Regional } \\
\text { Tax }\end{array}$ & $\begin{array}{l}\text { Organisasional support theory suggest that perceived } \\
\text { organisasional support may influence the employees } \\
\text { behavior and performance. This study aims to investigate } \\
\text { the influence of the quality of the tax apparatus and } \\
\text { perceived organizational support on efforts to optimize } \\
\text { local tax revenue. To accomplish this purpose, a survey } \\
\text { was conducted to regional tax apparatur in Sumatera. This } \\
\text { study uses purposive sampling involving } 60 \text { respondents. } \\
\text { The results of this study show that the quality of the tax } \\
\text { apparatus does not affect the efforts to optimize local tax } \\
\text { revenue. Then, the perceived organizational support has a } \\
\text { positive and significant influence on the effort to optimize } \\
\text { local tax revenue. However, perceived organizational } \\
\text { support does not moderate the influence of the quality of } \\
\text { the tax apparatus on efforts to optimize local tax revenue. } \\
\text { These findings imply that local governments need to } \\
\text { improve the quality of the apparatus to obtain organization } \\
\text { goals. In addition, local governments need to pay attention } \\
\text { to the employee in order to triggering organizational goals } \\
\text { attainment. }\end{array}$ \\
\hline
\end{tabular}

\section{PENDAHULUAN}

Penerimaan pajak daerah mempunyai peranan yang sangat penting karena merupakan komponen terbesar penerimaan Pendapatan Asli Daerah. Sebagai tumpuan penerimaan Pendapatan Asli Daerah, pemungutan dan penagihan pajak daerah harus dioptimalkan. Meskipun demikian, penerimaan daerah dari sektor pajak dinilai belum optimal dan mengakibatkan penerimaan pajak daerah tidak mencapai target maksimal. Salah satu determinan capaian yang belum menggembirakan tersebut diduga karena masih kurang optimalnya kinerja pegawai dalam melaksanakan tugas pokok dan fungsinya. Salah satu faktor yang diduga menjadi penyebab tidak optimalnya penerimaan pajak daerah adalah terbatasnya mutu sumber daya manusia pengelola pajak.

Sumber daya manusia merupakan salah satu bagian esensial dan aset berharga dalam sebuah organisasi yang mempunyai peran signifikan dalam keefektifan, 
pencapaian tujuan dan produktivitas organisasi (Wheelen dan Hunger, 2013). Waheed, dkk., (2019) menyatakan bahwa kesesuaian individu-organisasional sebagai determinan penting kinerja organisasi. Simamora (2006) menyatakan bahwa sumber daya manusia merupakan aset organisasi yang paling penting dan membuat sumber daya organisasi lainnya bekerja. Tanpa sumber daya manusia berkualitas, sumber daya lainnya akan menganggur dan kurang optimal pemanfataannya dalam pencapaian tujuan organisasi. Rhoades dan Eisenberger (2002) menyatakan bahwa pemberi kerja secara umum memberi nilai untuk dedikasi dan loyalitas pegawainya. Sebagai balikannya, pegawai akan memberikan komitmen terhadap organisasi dan kemudian menunjukkan peningkatan kinerja. Norma timbal-balik organisasi-pegawai memungkinkan terjadinya rekonsiliasi tujuan yang mungkin tidak selalu sama antara keduanya. Oleh karena itu, perlu dipastikan bahwa pengelolaan sumber daya manusia dilakukan sebaik mungkin agar mampu memberikan kontribusi secara optimal dalam upaya pencapaian tujuan organisasi.

Tajeddini dan Trueman (2008) menambahkan bahwa dalam lingkungan yang kompetitif, kinerja organisasi sangat tergantung kepada karyawannya baik untuk bertahan maupun berkompetisi. Istiningsih (2006) dalam Sriwidodo, dkk., (2010), menyaratakan bahwa kinerja individu dalam organisasi dipengaruhi oleh faktor individu, psikologis dan organisasi. Penelitian ini mempertimbangkan kedua faktorfaktor tersebut dalam upaya peningkatan penerimaan pajak daerah. Faktor individu yang ingin diuji adalah kualitas staf, sedangkan faktor psikologis dan organisasi adalah dukungan organisasional cerapan (perceived organizational support). Faktor-faktor tersebut harus diperhatikan dan diharapkan dapat mempengaruhi kinerja pegawai melaksanakan tugasnya dalam pemungutan pajak. Apabila kinerja pegawai baik maka tujuan organisasi dalam hal penerimaan pajak daerah dapat dicapai secara optimal. Aparat pajak sebagai salah satu sumber daya manusia yang ada pada instansi perpajakan bertugas untuk melakukan pemungutan pajak kepada wajib pajak. Kualitas aparat pajak menjadi faktor penting dalam meningkatkan penerimaan pajak.

Aparat pajak yang berkualitas adalah individu-individu yang kompeten, bertanggungjawab dan memiliki kecakapan teknis yang didukung dengan latar belakang pendidikan, pelatihan, dan pengalaman yang memadai (Sembiring, 2013). Dengan latar belakang pendidikan yang sesuai dengan pekerjaannya, aparat pajak akan lebih mudah memahami dan melaksanakan tugasnya. Ditambah dengan pelatihan yang telah diikuti maka akan menjadikan aparat pajak lebih terampil dan lebih produktif. Untuk memaksimalkan kinerja seorang pegawai dibutuhkan dukungan dari organisasi agar dapat meningkatkan semangat dan kualitas kinerja pegawai 
tersebut. Menurut Rhoades dan Einsenberger (2002), dukungan organisasi persepsian merupakan persepsi pegawai terhadap organisasi mengenai sejauh mana organisasi menghargai kontribusi dan peduli tentang kesejahteraan mereka. Teori dukungan organisasi (Eisenberger dkk., 1986) menyiratkan bahwa umumnya organisasi memberikan berbagai bentuk dukungan positif yang bermanfaat bagi pegawai. Dukungan organisasi kepada pegawai menurut Eisenberger, dkk., (1986) dapat ditunjukkan melalui penghargaan dari organisasi kepada pegawai, dukungan atasan, kondisi lingkungan kerja yang nyaman dan aman bagi pegawai, dan ada perhatian terhadap kesejahteraan pegawai. Pegawai cenderung untuk lebih berkomitmen memenuhi kewajibannya kepada organisasi apabila merasa organisasi telah mendukung setiap aktivitasnya. Semakin besar dukungan yang diberikan kepada pegawai, maka rasa ikatan emosional dalam diri pegawai akan meningkat terhadap organisasi karena merasa dirinya dihargai dan dipedulikan. Dukungan yang diberikan tersebut dapat menimbulkan persepsi positif pegawai terhadap organisasi. Pegawai dengan tingkat dukungan organisasional cerapan yang tinggi akan berusaha bekerja lebih maksimal, dan sebagai konsekuensi, tujuan organisasi dalam hal penerimaan pajak daerah dapat dicapai secara optimal.

Penelitian yang dilakukan Eisenberger, dkk., (1990) dalam Grafland, dkk., (2004) mengenai pengaruh dukungan organisasi persepsian terhadap kinerja pegawai, menunjukkan bahwa dukungan organisasi persepsian berpengaruh positif terhadap kinerja pegawai. Beberapa penelitian serupa yang dilakukan oleh Arshadi (2011), Afzali, dkk., (2014) dan Susmiati, dkk., (2015). Mereka menguji dan menemukan terdapatnya pengaruh dukungan organisasi persepsian terhadap kinerja pegawai. Semua penelitian tersebut menunjukkan bahwa dukungan organisasi persepsian berpengaruh terhadap kinerja pegawai. Meskipun demikian, Wann-Yih, dkk., (2011) dan Chiang, dkk., (2012) menemukan bahwa dukungan organisasi persepsian tidak berpengaruh terhadap kinerja pegawai. Hal ini mengindikasikan bahwa dukungan organisasi yang mereka rasakan tidak terlalu diperhatikan, sehingga bukan menjadi hal yang penting dan menjadikan alasan untuk meningkatkan kinerja mereka.

$$
\text { Penjelasan }
$$

tersebut mengisyaratkan bahwa bahwa penerimaan pajak suatu daerah dipengaruhi oleh faktor kualitas sumber daya manusia yang dalam hal ini adalah aparat pajak sebagai pihak yang melakukan pemungutan pajak terhadap wajib pajak. Selain itu faktor seperti dukungan organisasional cerapan juga dapat menjadi pemicu dalam meningkatkan penerimaan pajak. Hal ini dikarenakan aparat pajak sebagai sumber daya mausia membutuhkan dorongan dan semangat dari organisasi dalam menjalankan pekerjaannya. Semakin baik dukungan organisasional cerapan yang diberikan oleh organisasi maka akan semakin baik pula kinerja aparat 
pajak. Penelitian ini bertujuan untuk menginvestigasi pengaruh kualitas aparat pajak dan dukungan organisasional cerapan terhadap upaya optimalisasi penerimaan pajak daerah, dan meneliti pengaruh dukungan organisasional cerapan sebagai variabel moderasi antara kualitas aparat pajak terhadap upaya optimalisasi penerimaan pajak daerah. Penelitian ini berkontribusi secara teoretis dan praktis. Secara empiris, teori ini memberikan tambahan terhadap literatur teori organisasi dengan pengujian teori dukungan organisasi dan norma timbal balik dalam konteks pemungutan pajak daerah. Sebagai bentuk kontribusi praktis, temuan penelitian ini menyiratkan pentingnya dukungan organisasional dalam menopang karakteristik individual pegawai, seperti kualitas, dalam mencapai tujuan dan meningkatkan produktifitas organisasi

\section{KERANGKA TEORITIS}

\section{Pajak Daerah dan Optimalisasi Pemungutannya}

Pembangunan

daerah

merupakan salah satu wujud dari pembangunan nasional yang dilaksanakan berdasarkan prinsip otonomi daerah dengan tujuan untuk meningkatkan pendapatan dan kesejahteraan masyarakat daerah. Masing-masing daerah diberi kewenangan untuk menyusun, mengatur, dan mengurus daerahnya sendiri. Pemerintah pusat membuat kebijakan tersebut agar daerahnya lebih mandiri dalam meningkatkan sumber penerimaan guna membiayai penyelenggaraan pemerintah dan pembangunan daerah. Di Indonesia otonomi tersebut salah satunya diwujudkan dalam bentuk pemberian kewenangan kepada daerah untuk memungut pajak daerah. Menurut UU No. 28 Tahun 2009 (Pasal 1, Ayat 6) tentang Pajak Daerah dan Retribusi Daerah, yang dimaksud dengan Pajak Daerah adalah iuran wajib yang dilakukan oleh orang pribadi atau badan kepada daerah tanpa imbalan langsung yang seimbang, yang dapat dipaksakan berdasarkan peraturan perundang-undangan yang berlaku, yang digunakan untuk membiayai penyelenggaraan pemerintah daerah dan pembangunan daerah.

Masih rendahnya tingkat kepatuhan dan kesadaran Wajib Pajak terhadap pajak yang seharusnya dibayarkan menyebabkan penerimaan pajak tidak optimal. Berkaitan dengan hal tersebut maka perlu dilakukan upaya-upaya yang dapat mengoptimalkan penerimaan pajak daerah seperti memperkuat aparat pajak dengan meningkatkan kualitas aparat tersebut. Jika pemerintah memiliki aparatur yang berkualitas maka kinerja pemerintah diharapkan dapat meningkat sehingga penerimaan pajak dapat maksimal.

Salah satu upaya pemerintah dalam mengoptimalkan penerimaan pajak daerah yaitu dengan melakukan ekstensifikasi pajak dan intensifikasi pajak. Kementerian keuangan mengeluarkan kebijakan mengenai pelaksanaan ekstensifikasi dan intensifikasi pajak yang difokuskan untuk menggali potensi penerimaan pajak dan mengatasi wajib pajak yang tidak melaksanakan kewajiban perpajakannya. Ekstensifikasi pajak dimaksudkan sebagai upaya 
peningkatan penerimaan pajak melalui perluasan pungutan pajak (Soemitro, 1990), Ekstensifikasi dapat dilakukan diantaranya dengan memperluas basis perpajakan seperti menambah wajib pajak dan menciptakan jenis/varian pajak-pajak baru, atau memperluas ruang lingkup pajak yang ada.

Sementara itu, Soemitro (1990) mendefinisikan intensifikasi sebagai upaya memaksimalkan berbagai kebijakan yang selama ini telah dilaksanakan, melalui peningkatan efisiensi dan efektivitas penerimaan pajak daerah, perbaikan sistem administrasi atau peningkatan tarif pajak, dan memperbaiki sistem perpajakan daerah. Upaya intensifikasi dapat dilakukan dengan beberapa cara diantaranya

penyempurnaan administrasi pajak, peningkatan mutu pegawai atau petugas pemungut, dan penyempurnaan Undang-Undang pajak. Dengan melakukan intensifikasi pegawai artinya pemerintah dapat memperkuat pegawai dengan memperhatikan kualitas serta memberikan dukungan kepada pegawai yang mana nantinya akan meningkatkan kinerja pegawai sehingga dapat mengoptimalkan penerimaan pajak.

\section{Kinerja Pegawai}

Kinerja pegawai sering diartikan sebagai pencapaian tugas, dimana pegawai dalam bekerja harus sesuai dengan program kerja organisasi untuk menunjukkan tingkat kinerja organisasi dalam mencapai visi, misi dan tujuan organisasi (Sidanti, 2015). Sedangkan Sinambela (2012) mengemukakan bahwa kinerja pegawai didefinisikan sebagai kemampuan pegawai dalam melakukan sesuatu keahlian tertentu.

Keberhasilan suatu organisasi dalam rangka mencapai tujuan tergantung dari kemampuan dan keandalan sumber daya manusia yang mengoperasikan unit-unit kerja yang terdapat di dalam organisasi bersangkutan. Untuk itu diperlukan kinerja yang tinggi dari pelaku-pelaku kegiatan tersebut. Kinerja pegawai adalah hasil kerja secara kualitas dan kuantitas yang dicapai oleh seorang pegawai dalam melaksanakan tugasnya sesuai dengan tanggungjawab yang diberikan kepadanya (Mangkunegara, dkk., 2015). Dari pendapat tersebut diketahui bahwa kinerja adalah hasil kerja yang telah dicapai oleh seseorang atau sekelompok orang sesuai dengan tanggung jawab yang diberikan yang diukur dalam satuan dan waktu tertentu.

\section{Kualitas Aparat Pajak}

Sumber Daya Manusia (SDM) adalah salah satu elemen organisasi yang mempunyai peranan penting bahkan tidak dapat dilepaskan dari sebuah organisasi, baik institusi maupun perusahaan. SDM juga merupakan kunci keberhasilan suatu organisasi atau perusahaan, oleh karena itu harus dilakukan pengelolaan yang baik agar sumber daya manusia yang ada mampu memberikan kontribusi secara optimal dalam upaya pencapaian tujuan organisasi.

Koswara (2001:266-267) dalam Soloha (2015) menyatakan bahwa konteks kualitas sumber daya aparatur di era otonomi adalah kemampuan 
profesional dan keterampilan teknis para pegawai yang termasuk kepada unsur staf dan pelaksana di lingkungan Pemerintah Daerah. Hal ini sangat diperlukan agar manajemen pemerintahan dalam otonomi daerah dapat berlangsung secara efektif dan efisien. Yang diperlukan tidak hanya jumlahnya yang cukup, tetapi juga kualitas para pegawai yang harus diukur dengan melihat latar belakang pendidikan, pengalaman kerja, jenjang kepangkatan, status kepegawaian serta pelatihan yang telah diikuti.

Berdasarkan pengertian di atas dapat diketahui bahwa yang dimaksud dengan kualitas sumber daya manusia dalam penelitian ini adalah kemampuan aparat pajak untuk melakukan semua pekerjaannya dalam hal pemungutan pajak agar penerimaan pajak daerah dapat optimal.

\section{Dukungan Organisasional Cerapan}

Proses interaksi sosial bisa terjadi antara individu dengan individu, individu dengan kelompok, kelompok dengan kelompok. Dalam organisasi, interaksi sosial bisa terjadi dalam konteks individu dengan organisasinya. Terkait dengan itu, konsep dukungan organisasi mencoba menjelaskan interaksi individu dengan organisasi yang secara khusus mempelajari bagaimana organisasi memperlakukan pegawainya.

Pegawai dalam sebuah organisasi akan cenderung untuk membentuk sebuah kepercayaan secara umum terkait sejauh mana organisasi menghargai kontribusi pegawai dan peduli atas kesejahteraannya. Cerapan yang dirasakan oleh pegawai inilah yang sering juga disebut dengan dukungan organisasional cerapan. Dukungan organisasional cerapan dinilai sebagai jaminan bahwa bantuan akan tersedia dari organisasi pada saat dibutuhkan untuk menjalankan pekerjaan seseorang secara efektif dan pada saat menghadapi situasi yang sangat menegangkan (Rhoades dan Eisenberger, 2002). Sementara itu Robbins, dkk., (2008) dalam Ariarni, dkk., (2017) mendefinisikan dukungan organisasi persepsian sebagai tingkat sejauh mana pegawai yakin kontribusi dan kesejahteraannya dihargai organisasi. Sedangkan menurut Wayne, dkk., (1997) dukungan organisasi persepsian adalah keyakinan global yang dikembangkan oleh pegawai mengenai sejauh mana komitmen organisasi pada mereka (pegawai) dilihat dari penghargaan organisasi terhadap kontribusi mereka dan perhatian organisasi terhadap kehidupan mereka (Kambu, dkk., 2011).

Dukungan organisasi cerapan dapat diukur melalui indikator penghargaan, dukungan atasan, kondisi kerja, dan kesejahteraan pegawai (Eisenberger, dkk., 1986). Indikator penghargaan berkaitan dengan pengakuan organisasi atas kontribusi pegawai yang rela bekerja dengan baik dan memuaskan. Sedangkan dukungan atasan berkaitan dengan dukungan pimpinan terhadap pekerjaan bawahannya, artinya pimpinan memberi kepercayaan penuh kepada bawahan dalam menjalankan peran namun tetap 
melakukan pengawasan selama proses. Adapun indikator kondisi kerja berkaitan dengan bagaimana kondisi di lingkungan kerja misalnya mengenai sejauh mana hubungan atasan dan bawahan terjalin sehingga tercipta kondisi kerja yang baik. Sedangkan indikator kesejahteraan pegawai berkaitan dengan sejauh mana pegawai merasakan kepedulian organisasi pada kesejahteraan pegawai. Pada saat pegawai merasa didukung dan dihargai oleh organisasinya maka akan muncul keinginan pegawai membalas budi dengan melakukan hal positif untuk organisasi sehingga berdampak pada meningkatnya kinerja pegawai.

\section{Pengembangan Hipotesis}

Pengaruh Kualitas Aparat Pajak Terhadap Upaya Optimalisasi Penerimaan Pajak Daerah

Keberhasilan suatu organisasi tidak terlepas dari kualitas sumber daya manusia yang bekerja sama dalam mencapai tujuan kegiatan organisasi tersebut. Sumber daya manusia dapat dikatakan berkualitas apabila mereka mempunyai kemampuan untuk melaksanakan kewajiban dan tanggung jawab yang diberikan. Kemampuan tersebut hanya dapat dicapai ketika mereka mempunyai latar belakang pendidikan yang sesuai dengan bidang pekerjaannya Selain itu dengan mendapatkan pelatihan yang sesuai dengan bidang pekerjaannya, mereka akan lebih mudah melaksanakan tugasnya. Oleh karena itu setiap organisasi termasuk instansi pemerintah dituntut untuk mampu meningkatkan kualitas sumber daya manusia baik melalui program pendidikan maupun pelatihan. Tanpa adanya sumber daya yang berkualitas maka setiap organisasi akan kesulitan untuk mencapai tujuannya.

Kualitas aparat pajak dapat menentukan hasil pelayanan yang akan diberikan pemerintah kepada masyarakat sehingga peningkatan kualitas aparat pajak sangat penting keberadaannya untuk meningkatkan produktivitas kerja di lingkungan organisasi secara langsung. Hal ini dapat berdampak pada peningkatan pendapatan asli daerah karena pelayanan yang berkualitas akan mempengaruhi kepuasan wajib pajak sehingga menumbuhkan kesadaran wajib pajak untuk menyetorkan pajak daerah. Oleh karena itu aparatur dinas pendapatan daerah harus mampu berinovasi dalam melakukan pelayanan pajak daerah demi memberikan kepuasan kepada wajib pajak.

Manusia sebagai perencana, pelaku dan penentu terwujudnya tujuan organisasi.Tujuan ini tidak mungkin dapat dicapai tanpa peran aktif pegawai. Tanpa adanya SDM yang mampu bekerja secara maksimal, maka tujuan organisasi pun tidak dapat dicapai secara optimal. Dalam hal ini, aparat pajak sebagai sumber daya manusia yang ada di instansi perpajakan harus berkualitas agar dapat menghasilkan kinerja yang baik sehingga tujuan organisasi dapat dicapai secara maksimal. Hal tersebut menjadikan kualitas aparat pajak sebagai salah satu faktor dalam 
mengoptimalkan penerimaan pajak daerah.

Penelitian ini mendukung penelitian Sitohang (2009) dan Kasanudin (2011) bahwa kualitas SDM berpengaruh terhadap kinerja karyawan. Penelitian serupa juga dilakukan Aisyah, dkk (2017) yang menggunakan kualitas sumber daya manusia sebagai variabel bebas dan kinerja karyawan sebagai variabel terikat. Hasil penelitian membuktikan bahwa kualitas sumber daya manusia berpengaruh positif dan signifikan terhadap kinerja karyawan. Berbeda dengan penelitian Sibagariang (2013) yang menemukan bahwa kualitas sumber daya manusia tidak berpengaruh terhadap kinerja pegawai. Berdasarkan penjelasan tersebut dirumuskan hipotesis 1 sebagai berikut:

H1: Kualitas aparat pajak
berpengaruh positif terhadap upaya
optimalisasi penerimaan pajak
daerah

\section{Pengaruh}

Dukungan

Organisasional Cerapan Terhadap Upaya Optimalisasi Penerimaan Pajak Daerah

Dukungan

organisasional

cerapan merupakan cerapan pegawai mengenai dukungan organisasi terhadap pekerjaan yang mereka lakukan. Dukungan organisasional cerapan diyakini sebagai aspek penting dalam organisasi karena mampu meningkatkan kinerja pegawai. Pegawai yang merasa diperhatikan dan dihargai oleh organisasi akan menimbulkan rasa ikatan emosional dari dirinya sehingga pegawai akan lebih baik dalam melakukan pekerjaan.

Sebagian besar bukti empiris sebagaimana dirangkum dalam Rhoades dan Einsenberger (2002) menunjukkan bahwa pegawai dengan dukungan organisasional cerapan tinggi akan menilai pekerjaan mereka lebih menyenangkan (yang diindikasikan oleh peningkatan kepuasan kerja, munculnya mood positif dan penurunan stres), dan lebih terikat dengan organisasi (yang ditunjukkan oleh meningkatnya komiten organisasional, peningkatan kinerja dan penurunan turn-over. Hal ini dapat dimaknai bahwa jika pegawai menganggap dukungan organisasi yang diterimanya tinggi, maka pegawai akan berusaha untuk menyatu sebagai anggota organisasi dan menjadikan organisasi tersebut sebagai identitas diri mereka. Selain itu meraka juga akan mengembangkan hubungan dan cerapan yang lebih positif terhadap organisasi tersebut.

Organisasi harus memberikan dukungan terhadap pegawainya sebagai sumber daya manusia utama organisasi agar pegawai memiliki cerapan yang baik tentang organisasi tempatnya bekerja. Organisasi umumnya memberikan bentuk-bentuk dukungan positif kepada pegawai misalnya dengan memberi persetujuan, rasa hormat, perlakuan adil, gaji, promosi, hak bersuara, akses informasi serta bantuan lain yang dapat menunjang pelaksanaan pekerjaan dan kesejahteraan. Berbagai bentuk penerimaan tersebut pegawai merasa bertanggung jawab untuk berkontribusi dan memberikan kinerja terbaiknya (Ariarni, dkk., 2017).

Penelitian tentang pengaruh dukungan organisasi persepsian 
terhadap kinerja karyawan sebelumnya dilakukan oleh Mursidta (2017) yang membuktikan bahwa adanya pengaruh signifikan dukungan organisasi persepsian terhadap kinerja karyawan. Hal serupa juga dilakukan oleh Arshadi (2011), Afzali, dkk., (2014) dan Susmiati, dkk., (2015) yang menguji pengaruh dukungan organisasi persepsian terhadap kinerja pegawai, hasilnya menunjukkan bahwa dukungan organisasi persepsian berpengaruh terhadap kinerja pegawai. Meskipun berbeda dengan penelitian Wann-Yih, dkk., (2011) dan Chiang, dkk., (2012) yang menemukan bahwa dukungan organisasi persepsian tidak berpengaruh terhadap kinerja pegawai. Sesuai dengan konteks riset ini, bahwa dalam upaya mengoptimalkan penerimaan pajak daerah, organisasi dapat menciptakan dukungan positif terhadap pegawai. Dengan dukungan tersebut pegawai akan meningkatkan kinerjanya dan tujuan organisasi dalam hal penerimaan pajak daerah dapat tercapai secara optimal. Hal tersebut membuat dukungan organisasional cerapan menjadi penting dalam meningkatkan penerimaan pajak daerah. Berdasarkan hal tersebut dirumuskan hipotesis 2 sebagai berikut:

\section{H2: Dukungan organisasional cerapan berpengaruh positif terhadap upaya optimalisasi penerimaan pajak daerah}

Dukungan Organisasional Cerapan Sebagai Pemoderasi Hubungan antara Kualitas Aparat

\section{Pajak terhadap Upaya Optimalisasi Penerimaan Pajak Daerah}

Kualitas pegawai dalam sebuah organisasi akan berpengaruh pada peningkatan kinerjanya. Kualitas pegawai memiliki peran yang penting pada setiap organisasi, karena kualitas setiap pegawai akan berdampak pada totalitas bekerja untuk tujuan organisasi. Pegawai yang mempunyai kualitas yang baik maka dalam melaksanakan tugas-tugas yang diberikan oleh atasan akan dilakukan secara maksimal sehingga dapat meningkatkan kinerjanya.

Mengacu kepada norma timbalbalik (norm of reciprocity) oleh Gouldner (1960), Neves dan Einsenberger (2012) menyiratkan bahwa respon karyawan terhadap dukungan organisasional cerapan akan menciptakan kemauan karyawan untuk mmberikan kinerja baik intra-role maupun extra-role. Dengan demikian, dukungan organisasional cerapan dibutuhkan sebagai pendorong perilaku bagi pegawai agar melaksanakan pekerjaan dengan baik. Adanya dukungan organisasi akan membuat pegawai lebih bertanggung jawab dengan pekerjaannya dan pencapaian target dapat dilakukan tepat waktu. Dengan demikian kualitas pegawai yang baik dan adanya pemberian dukungan dari organisasi diharapkan dapat meningkatkan kinerja pegawai dan akan berdampak pada optimalisasi penerimaan pajak daerah. Sebagai tambahan, dukungan organisasional diharapkan dapat mereduksi pengaruh negatif dari rendahnya kualitas staf terhadap pencapaian tujuan organisasi, dalam 
hal ini optimaliasi penerimaan pajak daerah. Berdasarkan dukungan teoretis dan empiris tersebut, hipotesis 3 dirumuskan sebagai berikut:

H3 : Dukungan organisasional cerapan memoderasi pengaruh kualitas aparat pajak terhadap upaya optimalisasi penerimaan pajak daerah

\section{METODOLOGI PENELITIAN}

Populasi yang digunakan dalam penelitian ini adalah pegawai pajak daerah di Sumatera. Teknik pengambilan sampel yang digunakan adalah penyampelan random dimana semua individu dalam populasi baik secara sendiri-sendiri atau bersamasama diberi kesempatan untuk dipilih menjadi anggota sampel. Metode yang digunakan adalah Purposive Sampling dengan kriteria utama responsen adalah aparatur pajak daerah dengan pengalaman kerja minimal 2 tahun. Metode pengumpulan data yang digunakan dalam penelitian ini adalah dengan menggunakan kuesioner yang disebar secara langsung dan secara daring (online). Skala pengukuran yang digunakan dalam penelitian ini adalah skala Likert, dengan interval jawaban 1 sampai 5 dengan menyesuaikan pernyataan yang diajukan. Kemudian, untuk meyakinkan bahwa tidak ada perbedaan respon antara responden yang diambil datanya secara langsung dan secara daring dilakukan uji-t. Kemudian untuk meyakinkan tidak adanya bias non-response dilakukan pengujian terhadap respon $10 \%$ responden awal dengan respon 10\% responden akhir. Pengujian dilakukan dengan uji-t (t-test).
Variabel dalam penelitian ini terdiri atas variabel independen yaitu kualitas aparat pajak (X1) dan dukungan organisasional cerapan (X2) dan variabel dependen yaitu upaya optimalisasi penerimaan pajak daerah. Upaya optimalisasi penerimaan pajak daerah merupakan suatu usaha pemerintah dalam meningkatkan penerimaan daerahnya guna membiayai penyelenggaraan dan pembangunan daerah. Indikator pengukuran untuk upaya optimalisasi penerimaan pajak daerah meliputi: profesionalitas, ketepatan waktu, sosialisasi, dan sistem administrasi. Sementara itu, kualitas aparat pajak adalah kemampuan aparat pajak dalam melaksanakan aktivitasaktivitas yang menjadi tanggung jawabnya untuk mencapai tujuan organisasi. Indikator pengukuran untuk kualitas aparat pajak meliputi: latar belakang pendidikan, pengalaman kerja, dan pelatihan yang pernah diikuti. Dukungan organisasional cerapan adalah tingkat sejauh mana pegawai yakin kontribusi dan kesejahteraannya dihargai organisasi. Indikator pengukuran untuk dukungan organisasional cerapan meliputi: penghargaan, dukungan atasan, kondisi kerja, dan kesejahteraan pegawai. Instrumen diadopsi dari Rhoades dan Eisenberger (2002). Analisis regresi berganda digunakan untuk pengujian hipotesis penelitian. Sebelum dilakukan pengujian hipotesis, dilakukan pengujian validitas dan reliabilitas serta asumsi klasik.

\section{HASIL \& PEMBAHASAN Responsen Penelitian}

Penyebaran kuesioner dilakukan oleh peneliti dengan menyebarkan kuesioner secara langsung kepada pegawai pajak daerah yang sedang mengikuti pelatihan perpajakan di Kota Padang, selain itu peneliti juga 
menyebarkan kuesioner kepada pegawai pajak daerah secara daring (online).

Kuesioner yang disebar dalam penelitian ini berjumlah 100 kuesioner yang terdiri dari 40 kuesioner langsung dan 60 kuesioner daring (online). Kuesinoner langsung disebarkan kepada aparatur pajak yang mengikuti pelatihan pajak daerah yang dilaksanakan oleh Direktorat Jenderal Perimbangan Keuangan dan Pusat Studi Keuangan dan Pembangunan Universitas Andalas di Padang, sedangkan kuesioner daring disebarkan melalui google form kepada peserta pelatihan yang sama pada angkatan sebelumnya. Dari 40 $(100 \%)$ kuesioner langsung yang disebar, semua kuesioner kembali dan dapat diolah. Dari 60 (100\%) kuesioner daring (online) yang disebar, 20 $(33,3 \%)$ kuesioner kembali dan dapat diolah. Persentase kuesioner yang siap diolah adalah $66,7 \%$ untuk kuesioner langsung dan 33,3\% untuk kuesioner daring (online).

Berdasarkan data yang telah dikumpulkan diperoleh deskripsi responden yang dapat diklasifikasikan berdasarkan jenis kelamin, usia, pendidikan, dan provinsi tempat bekerja.

Karakteristik demografi responden menunjukkan berdasarkan jenis kelamin adalah responden dengan jenis kelamin laki-laki sebanyak 43 responden $(71,7 \%)$ dan perempuan sebanyak 17 responden (28,3\%). Dengan demikian dapat dilihat bahwa mayoritas responden adalah laki-laki. Berdasarkan usia, responden terdiri dari usia < 30 tahun adalah 7 responden $(11,7 \%)$, usia $30-35$ tahun adalah 19 responden $(31,7 \%)$, usia 36 - 40 tahun adalah 20 responden (33,3\%), 41 - 45 tahun adalah 11 responden $(18,3 \%)$, dan usia $>46$ tahun adalah 3 responden (5\%). Kemudian, berdasarkan tingkat pendidikan responden terdiri dari tamatan SMA adalah 1 responden $(1,67 \%)$, tamatan Diploma adalah 4 responden $(6,67 \%)$, tamatan $\mathrm{S} 1$ adalah 40 responden $(66,66 \%)$, tamatan S2 adalah 15 responden (25\%), dan tamatan S3 adalah tidak ada responden. Sedangkan berdasarkan daerah tempat responden bekerja terdiri dari Provinsi Aceh adalah 4 responden $(6,67 \%)$, Provinsi Sumatera Utara adalah 17 responden (28,33\%), Provinsi Riau adalah 2 responden (3,33\%), Provinsi Kepulauan Riau adalah 3 responden (5\%), Provinsi Sumatera Barat adalah 19 responden $(31,67 \%)$, Provinsi Jambi adalah 3 responden (5\%), Provinsi Bengkulu adalah 5 responden $(8,33 \%)$, Provinsi Lampung adalah tidak ada responden, Provinsi Bangka Belitung adalah tidak ada responden, dan Provinsi Sumatera Selatan adalah 7 responden $(11,67 \%)$.

\section{Uji Validitas dan Reliabilitas}

Teknik yang digunakan untuk mengetahui kevalidan data yang diperoleh adalah dengan menggunakan uji validitas Pearson Correlation dengan aplikasi SPSS 25. Dengan taraf signifikansi sebesar $5 \%$ dan jumlah responden sebanyak 60 orang, maka akan diperoleh nilai $r$ tabel sebesar 0,254 , maka apabila $r$ hitung besar dari $r$ tabel ( $r$ hitung $>r$ tabel), maka pernyataan tersebut valid. Hasil uji validitas Pearson Correlation diatas menunjukkan setiap pernyataan pada variabel yaitu Upaya Optimalisasi Penerimaan Pajak Daerah (Y), Kualitas Aparat Pajak (X1), dan 
Dukungan Organisasional Cerapan (X2), signifikan pada tingkat signifikansi 0,05 . Dengan demikian dapat disimpulkan bahwa semua pernyataan yang terdapat dalam kuesioner dapat digunakan untuk mengukur variabel yang ada.

Teknik yang digunakan untuk mengetahui reliabilitas data yang diperoleh adalah dengan menggunakan uji statistik Cronbach's Alpha (a) pada aplikasi SPSS 25. Menurut Hair et al. (2010), jika koefisien Cronbach's Alpha menunjukkan nilai $\geq 0,80$ maka reliabilitas dinilai baik. Berdasarkan hasil pengujian reliabilitas, hasil perhitungan menunjukkan bahwa nilai Cronbach's Alpha ( $\alpha$ ) untuk setiap variabel adalah lebih besar dari 0,60. Sehingga dapat disimpulkan bahwa jawaban dari pernyataan yang diperoleh untuk masing-masing variabel dapat dikatakan andal. Demikian pula, hasil pengujian asumsi klasik yang terdiri dari uji normalitas, heteroskedastisitas, dan multikolinearitas menunjukkan dukungan terhadap semua asumsi klasik yang diuji.

\section{Hasil Pengujian Non-Response Bias dan Teknik Pengambilan Data}

Teknik pengambilan data pada penelitian ini adalah dengan menggunakan kuesioner yang disebar secara langsung dan daring (online). Untuk meyakinkan bahwa tidak ada perbedaan respon antara responden yang diambil datanya secara langsung dan secara daring (online) maka perlu dilakukan pengujian data antara teknik pengambilan data tersebut yang dilakukan dengan uji-t (t-test). Hasil pengujian dapat dilihat pada tabel 1 .

Berdasarkan hasil uji beda antara kuesioner yang diisi secara langsung dan diisi secara daring (online), didapatkan nilai signifikan sebesar 0,119 yang lebih besar dari 0,05 . Sehingga, dapat disimpulkan bahwa respon dari kuesioner yang diisi secara langsung maupun secara daring (online) tidak ditemukan adanya perbedaan antara keduanya.

Selanjutnya pengujian nonresponse bias dilakukan untuk meyakinkan bahwa tidak adanya perbedaan antara respon dari responden yang mengisi kuesioner dengan respon dari responden yang tidak mengisi kuesioner. Menurut Armstrong, dkk., (1977) responden yang merespon lebih lambat atau paling lambat adalah sama dengan orang yang tidak merespon. Pengujian ini dilakukan terhadap respon $10 \%$ responden awal dengan respon 10\% responden akhir. Pengujian dilakukan dengan uji-t (t-test). Hasil pengujian non-response bias dapat dilihat pada tabel 2.

Sebagaimana dapat dilihat pada tabel 2, nilai signifikan yang dihasilkan sebesar 0,338 yang lebih besar dari 0,05. Hasil ini mengindikasikan bahwa tidak ada perbedaan yang signifikan antara responden yang mengisi kuesioner dengan responden yang tidak mengisi kuesioner Hal ini menunjukkan bahwa tidak ada bias antara responden awal dengan responden akhir. Dengan demikian, dapat disimpulkan bahwa tidak terdapat non-response bias dalam penelitian ini. 
Tabel 1

Hasil Uji Kuesioner Langsung dan Daring (online) Independent Samples Test

\begin{tabular}{|c|c|c|c|c|c|c|c|c|c|c|}
\hline & \multicolumn{2}{|c|}{$\begin{array}{l}\text { Levene's } \\
\text { Test for } \\
\text { Equality of } \\
\text { Variances }\end{array}$} & \multicolumn{7}{|c|}{ t-test for Equality of Means } \\
\hline & & \multirow[t]{2}{*}{$\mathrm{F}$} & \multirow[t]{2}{*}{ Sig. } & \multirow[t]{2}{*}{$T$} & \multirow[t]{2}{*}{ Df } & \multirow[t]{2}{*}{$\begin{array}{l}\text { Sig. } \\
(2- \\
\text { tailed) }\end{array}$} & \multirow[t]{2}{*}{$\begin{array}{l}\text { Mean } \\
\text { Differen } \\
\text { ce }\end{array}$} & \multirow{2}{*}{$\begin{array}{c}\text { Std. } \\
\text { Error } \\
\text { Differen } \\
\text { ce }\end{array}$} & \multicolumn{2}{|c|}{$\begin{array}{l}95 \% \text { Confidence } \\
\text { Interval of the } \\
\text { Difference }\end{array}$} \\
\hline & & & & & & & & & Lower & Upper \\
\hline \multirow[t]{2}{*}{ Dependent } & $\begin{array}{l}\text { Equal } \\
\text { variances } \\
\text { assumed }\end{array}$ & ,207 & 652 & $-1,594$ & 38 & ,119 &,- 20000 & ,12546 &,- 45398 & ,05398 \\
\hline & $\begin{array}{l}\text { Equal } \\
\text { variances } \\
\text { not } \\
\text { assumed }\end{array}$ & & & $-1,594$ & 37,970 & ,119 & -20000 & 12546 &,- 45398 & ,05399 \\
\hline
\end{tabular}

Sumber : Data Primer yang diolah, 2019

Tabel 2.

Hasil Uji Non-Response Bias

Independent Samples Test

\begin{tabular}{|c|c|c|c|c|c|c|c|c|c|c|}
\hline & \multicolumn{2}{|c|}{$\begin{array}{l}\text { Levene's } \\
\text { Test for } \\
\text { Equality of } \\
\text { Variances }\end{array}$} & \multicolumn{7}{|c|}{ t-test for Equality of Means } \\
\hline & & \multirow[t]{2}{*}{$\mathrm{F}$} & \multirow[t]{2}{*}{ Sig. } & \multirow[t]{2}{*}{$T$} & \multirow[t]{2}{*}{ Df } & \multirow[t]{2}{*}{$\begin{array}{l}\text { Sig. } \\
(2- \\
\text { tailed })\end{array}$} & \multirow[t]{2}{*}{$\begin{array}{c}\text { Mean } \\
\text { Differen } \\
\text { ce }\end{array}$} & \multirow{2}{*}{$\begin{array}{c}\text { Std. } \\
\text { Error } \\
\text { Differen } \\
\text { ce }\end{array}$} & \multicolumn{2}{|c|}{$\begin{array}{l}95 \% \text { Confidence } \\
\text { Interval of the } \\
\text { Difference }\end{array}$} \\
\hline & & & & & & & & & Lower & Upper \\
\hline \multirow[t]{2}{*}{ Dependent } & \begin{tabular}{|l|} 
Equal \\
variances \\
assumed
\end{tabular} & 007 & ,933 & 1,006 & 10 & ,338 & ,12500 & , 12430 &,- 15197 & ,40197 \\
\hline & $\begin{array}{l}\text { Equal } \\
\text { variances } \\
\text { not } \\
\text { assumed }\end{array}$ & & & 1,006 & 10,000 & ,338 & 12500 & 12430 &,- 15197 & ,40197 \\
\hline
\end{tabular}

Sumber : Data Primer yang diolah, 2019

\section{Statistik Deskriptif}

Statistik deskriptif memberikan informasi mengenai nilai terendah, tertinggi, rata-rata, dan standar deviasi masing-masing variabel yang diuji dalam penelitian ini. Hasil analisis

statistik deskriptif dapat dilihat pada tabel 3. Variabel upaya optimalisasi penerimaan pajak daerah mempunyai nilai rata-rata sebesar 4,1500 dan standar deviasi sebesar 0,41349. Hal ini menunjukkan bahwa upaya optimalisasi penerimaan pajak daerah sudah dilakukan dengan baik karena 
memiliki persentase yang tinggi yaitu $83 \%$. Nilai minimumnya sebesar 3,13 dan nilai maksimumnya sebesar 5,00. Variabel dukungan organisasional cerapan mempunyai nilai rata-rata sebesar 3,8583 dan standar deviasi sebesar 0,58922. Hal ini menunjukkan bahwa dukungan organisasi yang diberikan kepada aparat pajak dinilai cukup baik karena memiliki persentase yang cukup tinggi yaitu 77\%. Nilai minimumnya sebesar 2,00 dan nilai maksimumnya sebesar 4,88. Sementara itu, sebagaimana disajikan pada tabel 3, variabel Kualitas Aparat Pajak mempunyai nilai rata-rata sebesar 2,8944 dengan persentase $58 \%$ dan standar deviasi sebesar 0,54025 . Hal ini menunjukkan bahwa kualitas yang dimiliki aparat pajak tidak terlalu tinggi karena hanya memiliki persentase $58 \%$. Nilai minimumnya sebesar 1,67 dan nilai maksimumnya sebesar 4,33

\section{Tabel 3.}

Statistik Deskriptif

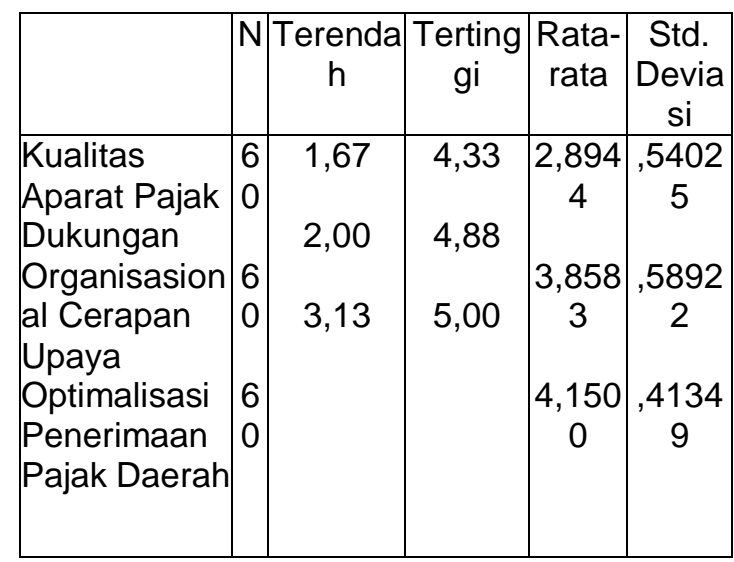

\section{Pengujian Hipotesis}

Pengujian hipotesis dilakukan dengan analisis regresi multipel. Analisis ini digunakan untuk mengetahui seberapa besar pengaruh variabel bebas yaitu Kualitas Aparat Pajak (X1) dan Dukungan
Organisasional Cerapan/DOC terhadap variabel terikat yaitu Upaya Optimalisasi Penerimaan Pajak Daerah (Y). Hasil pengujian disajikan pada tabel 4 berikut:

Tabel 4.

Hasil Analisis Regresi Multipel

\begin{tabular}{|c|c|c|c|c|}
\hline $\begin{array}{c}\text { Mod } \\
\text { el }\end{array}$ & $\begin{array}{l}\text { Unstandard } \\
\text { ized } \\
\text { Coefficients }\end{array}$ & $\begin{array}{l}\text { Standardi } \\
\text { zed } \\
\text { Coefficie } \\
\text { nts }\end{array}$ & $t$ & $\begin{array}{l}\mathrm{Si} \\
\mathrm{g} .\end{array}$ \\
\hline
\end{tabular}

\begin{tabular}{|l|r|r|r|r|r|}
\hline & & & & & \\
\cline { 2 - 5 } & B & $\begin{array}{r}\text { Std. } \\
\text { Erro } \\
\mathrm{r}\end{array}$ & Beta & & \\
\hline & 2,875 &, 42 & & 6,77 &, 00 \\
1 (Constant) & & 5 & & 1 & 0 \\
\hline Kualitas &, 143 &, 09 &, 186 & 1,51 &, 13 \\
\hline DOC &, 223 &, 08 &, 318 & 2,59 & 5 \\
\hline $\begin{array}{l}\text { Kualitas*D } \\
\text { OC }\end{array}$ &,- 270 &, 20 & $-1,084$ & 2 & 2 \\
\hline
\end{tabular}

Tabel 4 di atas menunjukkan bahwa kualitas aparat pajak tidak berpegaruh signifikan terhadap upaya optimalisasi penerimaan pajak daerah $(\mathrm{t}=1,515 ; \quad p=0,135)$. Hal ini mengindikasikan bahwa $\mathrm{H} 1$ gagal didukung. Kemudian, variabel dukungan organisasional cerapan menunjukkan nilai signifikan sebesar 0,012 dan $t$ sebesar 2,592. Hasil ini menunjukkan bahwa terdapat pengaruh signifikan dari dukungan organisasional cerapan terhadap upaya optimalisasi penerimaan pajak daerah. Dengan demikian, H2 terdukung. Selanjutnya, pengujian pengaruh moderasi dukungan 
organisasional cerapan menunjukkan nilai signifikan $0,190>0,05$ dan nilai $t$ hitung $(-1,327)<t$ tabel 2,000. Hasil ini menunjukkan bahwa dukungan organisasional cerapan gagal memoderasi hubungan antara kualitas aparatur pajak dan optimalisasi penerimaan pajak daerah. Dengan demikian, $\mathrm{H} 3$ gagal terdukung.

Selanjutnya, berdasarkan pengujian yang telah dilakukan diperoleh hasil uji Koefisien Determinasi $\left(R^{2}\right)$ sebesar 0,141 yang berarti bahwa $14,1 \%$ variasi besarnya upaya optimalisasi penerimaan pajak daerah dapat dijelaskan oleh variasi kualitas aparat pajak dan dukungan organisasional cerapan. Sedangkan sisanya sebesar $85,9 \%$ dijelaskan oleh variabel lain diluar model penelitian ini.

\section{Pembahasan}

Berdasarkan pengolahan data penelitian yang telah dilakukan diperoleh kesimpulan bahwa kualitas aparat pajak tidak berpengaruh terhadap upaya optimalisasi penerimaan pajak daerah. Oleh karena itu dapat disimpulkan bahwa tingkat kualitas aparat pajak di Sumatera secara umum tidak terlalu tinggi, hal ini dapat dilihat dari nilai rata-rata pada statistik deskriptif sebesar 2,8944 dengan persentase $58 \%$ dari kondisi ideal. Hal tersebut perlu diperhatikan instansi organisasi pemerintah terutama di bidang pajak agar dapat meningkatkan kualitas aparat pajaknya sehingga penerimaan pajak daerah dapat dicapai secara optimal. Peningkatan kualitas aparat pajak bisa dengan menempatkan pegawai sesuai dengan latar belakang pendidikannya serta memberikan pelatihan kepada pegawai di bidang pajak. Sebagaimana disarankan oleh Sembiring (2013), dengan latar belakang pendidikan yang sesuai dengan pekerjaannya, aparat pajak akan lebih mudah memahami dan melaksanakan tugasnya. Ditambah dengan pelatihan yang telah diikuti maka akan menjadikan aparat pajak lebih terampil dan lebih produktif. Sembiring juga menyiratkan bahwa aparat pajak yang berkualitas adalah individu-individu yang kompeten, bertanggungjawab dan memiliki kecakapan teknis yang didukung dengan latar belakang pendidikan, pelatihan, dan pengalaman yang memadai. Oleh karena itu, perlu menjadi perhatian para pemangku kepentingan untuk tetap melakukan berbagai upaya untuk meningkatkan kualitas aparatur pajak daerah. Bukti anekdotal menunjukkan bahwa 
aparatur pajak daerah masih terbatas secara kuantitas dan kualitas. Hal ini dapat dilihat dari masih sangat sedikitnya daerah yang mempunyai juru sita pajak, pejabat penyidik dan pejabat fungsional pemeriksaan pajak yang kompeten dan telah dilantik oleh kepala daerah masing-masing.

Hasil pengujian hipotesis berikutnya menunjukkan bahwa variabel dukungan organisasional cerapan berpengaruh terhadap upaya optimalisasi penerimaan pajak daerah. Dalam penelitian ini cerapan pegawai terhadap dukungan organisasinya bernilai positif. Artinya semakin tinggi tingkat dukungan organisasional cerapan yang dirasakan pegawai maka semakin baik kinerja yang akan dihasilkan sehingga dapat mengoptimalkan penerimaan pajak daerah. Temuan ini konsisten dengan penjelasan teori dukungan organisasi (Einsenberger dkk., 1986) yang menyiratkan bahwa pegawai dengan cerapan dukungan organisasional akan memberikan kesan yang positif terhadap organisasi, mengerahkan lebih banyak upaya dan pada akhirnya mengalami peningkatan kinerja. Pegawai yang merasa didukung oleh organisasi bersedia tidak hanya menunjukkan in-role behavior, akan tetapi juga extra-role behavior. Dengan kata lain, mereka bersedia mengerahkan upaya dalam pencapaian tujuan organisasi di luar tanggungjawab pokok sesuai dengan tugas dan kewenangan yang diembannya.

Temuan ini juga menyiratkan bahwa organisasi harus membangun lingkungan yang mendukung terutama yang diberikan oleh pimpinan. Oleh karena itu pimpinan atau organisasi perlu memberikan dukungan yang lebih besar kepada aparat pajak agar optimalisasi penerimaan pajak daerah dapat dilakukan dengan baik. Dukungan dapat diberikan dalam bentuk penghargaan, dukungan atasan, kondisi kerja, dan kesejahteraan pegawai.

Terakhir, hasil pengujian hipotesis menunjukkan bahwa dukungan organisasional cerapan tidak berhasil memoderasi hubungan antara kualitas aparatur pajak dan optimalisasi penerimaan pajak daerah. Temuan ini mengindikasikan bahwa walaupun organisasi telah memberi dukungan kepada pegawai tetapi jika pegawai tersebut tidak memiliki kualitas yang tinggi maka tidak akan tercapai kinerja yang maksimal yang kemudian 
diharapkan memengaruhi upaya optimalisasi dalam penerimaan pajak daerah.

\section{KESIMPULAN}

Penelitian ini bertujuan untuk menguji pengaruh kualitas aparatur pajak dan dukungan organisasional cerapan terhadap upaya optimalisasi penerimaan pajak daerah. Hasil penelitian menunjukkan bahwa (1) Kualitas aparat pajak tidak berpengaruh terhadap upaya optimalisasi penerimaan pajak daerah, (2) Dukungan organisasional cerapan berpengaruh positif terhadap upaya optimalisasi penerimaan pajak daerah, dan (3) Dukungan organisasional cerapan tidak secara signifikan memoderasi pengaruh kualitas aparat pajak terhadap upaya optimalisasi penerimaan pajak daerah.

$$
\text { Hasil pengujian dengan }
$$

menggunakan koefisien determinasi $\left(R^{2}\right)$ memberikan bukti empiris bahwa pengaruh kualitas aparat pajak dan dukungan organisasional cerapan terhadap upaya optimalisasi penerimaan pajak daerah sebesar $14,1 \%$. Hasil ini menunjukkan bahwa $14,1 \%$ variasi besarnya upaya optimalisasi penerimaan pajak daerah dapat dijelaskan oleh variasi kualitas aparat pajak dan dukungan organisasional cerapan. Sedangkan sisanya sebesar $85,9 \%$ dijelaskan oleh faktor-faktor lain diluar penelitian ini.

Temuan ini mengimplikasikan bahwa pemerintah daerah masih perlu untuk meningkatkan meningkatkan kualitas baik dalam bentuk fasilitasi pendidikan formal maupun pelatihan terstruktur bagi aparatur pajak daerah.
Insentif ini diharapkan akan mampu mendorong pencapaian kinerja yang lebih baik. Kemudian, pemerintah daerah perlu mempertahankan dan bahkan meningkatkan dukungan terhadap para pegawai sehingga tercipta sikap dan perilaku positif dari pegawai yang kemudian akan mendorong pencapaian tujuan organisasi.

Penelitian ini mempunyai beberapa keterbatasan. Pertama, penelitian ini mengukur kualitas aparatur dengan pengalaman, pendidikan, dan pelatihan di bidang perpajakan. Kualitas itu sendiri adalah konsep dengan dimensi yang luas. Kedua, penelitian ini belum merata sebaran di semua provinsi di Sumatera. Ketiga, masih rendahnya tingkat respon untuk kuesioner daring (online). Penelitian berikutnya dapat menggunakan ukuran kualitas aparatur yang lebih representatif yang menangkap cakupan dimensi secara lebih komprehensif. Selain itu, peningkatan akses terhadap pemerintahan daerah dapat diharapkan untuk mendapatkan data yang lebih banyak.

\section{REFERENCES}

Afzali, A., Motahari, A.A., HatamiShirkouh, L. 2014. "Investigating The Influence of Perceived Organizational Support, Psychological Empowerment and Organizational Learning on Job Performance: An Empirical Investigation". Tehnički vjesnik 21 (3): $623-629$

Aisyah, M. F., dkk. 2017. Kualitas Sumber Daya Manusia, Profesionalisme Kerja, dan Komitmen sebagai Faktor Pendukung Peningkatan Kinerja 
Karyawan PDAM Kabupaten Jember. e-journal Ekonomi Bisnis dan Akuntansi, IV (1): 131 - 135

Ariarni, N. dan Afrianty, T. W. 2017. Pengaruh

Perceived

Organizational Support Terhadap Kinerja Karyawan Dengan Employee Engagement Sebagai Variabel Intervening (Studi pada Karyawan PT. Pos Indonesia Kota Madiun). Jurnal Administrasi Bisnis (JAB), 50 (4): 169-177

Armstrong, J., Scott., dan Overton, T., S. 1977. Estimating Nonresponse Bias in Mail Surveys. Published in Journal of Marketing Research, 14: 396 - 402

Arshadi, N. 2011. The Relationship of Perceived Organizational Support (POS) with Organizational Commitment, Inrole Performance, and Turnover Intention: Mediating Role of Felt Obligation. Procedia - Social and Behavioral Sciences 30: 11031108

Chiang, Chun-Fang, Tsung-Sheng Hsieh. 2012. "The Impacts of Perceived Organizational Support and Psychological Empowerment on Job Performance: The Mediating Effects of Organizational Citizenship Behavior". International Journal of Hospitality Management 31:180190

Eisenberger, R., R. Huntington, S. Dan Debora S. 1986. Perceived Organizational Support. Journal of Applied Psychology, 71 (3): 500-507

Grafland, J. dan Rutten, B. A. 2004. Perceived Organisational Support and Profitability. CentER Discussion Paper No. 2004 - 45. Hair, J. F. Jr., Black, W. C., Babin, B. J., \& Anderson, R. E. 2010. Multivariate Data Analysis. 7 th ed. Upper Saddle River, NJ: Prentice Hall.

Kambu, A., dkk. 2012. Pengaruh Leader-Member Exchange, Persepsi

Dukungan Organisasional, Budaya Etnis Papua dan Organizational Citizenship Behavior Terhadap Kinerja Pegawai pada Sekda Provinsi Papua. Jurnal Aplikasi Manajemen, 10 (2): 262 - 272

Kasanudin, Mukhamad. 2011. "Pengaruh Kualitas Sumber Daya Manusia (SDM) Pengelola Koperasi Terhadap Kinerja Koperasi Pondok Pesantren Di Kabupaten Demak". Thesis Fakultas Syari'ah, Institute Agama Islam Negeri Walisongo.

Mangkunegara, A. P., dan Waris, A. 2015. Effect of Training, Competence and Discipline on Employee Performance in Company (Case Study in PT. Asuransi Bangun Askrida). Procedia - Social and Behavioral Sciences 211: 1240 - 1251

Mursidta, S. 2017. Pengaruh Perceived Organizational Support (Persepsi Dukungan Organisasi) dan Kepuasan Kerja Terhadap Kinerja Karyawan Pada PT. Varia Usaha Beton Gresik. Jurnal IImu Manajemen, 5 (1):1-12

Revita, M. 2015. Pengaruh Kompetensi, Disiplin Kerja dan Lingkungan Kerja Terhadap Kinerja Pegawai pada Dinas Energi dan Sumber Daya Mineral Kabupaten Sigi. e Jurnal Katalogis, 3(9): 171 - 178

Rhoades, L. dan Eisenberger, $R$. 2002. Perceived Organizational Support : A Review of the Literature. Journal of Applied Psychology. 87 (4): 698-714 
Sekaran, Uma. 2006. Metode Penelitian Bisnis. Jakarta: Salemba Empat

Sembiring, Febriady. 2013. "Pengaruh Kualitas Sumber Daya Manusia, Pemanfaatan Teknologi Informasi Dan Sistem Pengendalian Intern Terhadap Keandalan Dan Ketepatwaktuan Pelaporan Keuangan Pemerintah". Skripsi Fakultas Ekonomi, Universitas Negeri Padang.

Sibagariang, A. 2013. Pengaruh Sumber Daya Manusia, Komunikasi, Sarana Pendukung, dan Komitmen Organisasi Terhadap Kinerja SKPD (Studi Empiris pada Pemerintah Kota Sibolga). Jurnal Akuntansi, 1(1): 1-24

Sidanti, H. 2015. Pengaruh Lingkungan Kerja, Disiplin Kerja dan Motivasi Kerja Terhadap Kinerja Pegawai Negeri Sipil di Sekretariat DPRD Kabupaten Madiun. Jurnal JIBEKA, Vol.9(1): $44-53$

Simamora, Henry. 2006. Manajemen Sumber Daya Manusia. Yogyakarta: STIE YKPN

Sinambela, Lijan. 2012. Kinerja Pegawai: Teori, Pengukuran dan Implikasi. Yogyakarta: Graha IImu

Sitohang, Sonang. 2009. Pengaruh Kualitas Sumber Daya Manusia Terhadap Kinerja Pengrajin Sentral Industri Kecil Tenun lkat. Sekolah Tinggi Ilmu Surabaya

Soemitro, Rachmat. 1990. Pengantar Singkat Hukum Pajak. Bandung: PT Eresco

Soloha, C. 2015. Kualitas Aparatu Pemerintah dalam Meningkatkan Pelayanan di Dinas Pendidikan Kabupaten Morotai. Jurnal Politico, Vol.2, No 6
Sriwidodo, U., dan Haryanto, A. B. 2010. Pengaruh Kompetensi, Motivasi, Komunikasi Dan Kesejahteraan Terhadap Kinerja Pegawai Dinas Pendidikan. Jurnal Manajemen Sumberdaya Manusia, 4 (1): 47-57

Susmiati dan Sudarma, K. 2015. Pengaruh Budaya Organisasi dan Dukungan Organisasi Persepsian Terhadap Kinerja Karyawan Dengan Komitmen Organisasi sebagai Variabel Intervening. Management Analysis Journal, Vol.4 (1): 79-87

Undang-Undang No. 28 Tahun 2009 tentang Pajak Daerah dan Retribusi Daerah

Undang-Undang No. 33 tahun 2004 tentang Perimbangan Keuangan Antara Pemerintah Pusat dan Daerah

Waheed, A.M., S. Fauzia, H. Mudassir dan S. Naseer. 2019. PersonOrganization Fit and Innovative Work Behavior: The Mediating Role of Perceived Organizational Support, Affective Commitment and Trust. Pakistan Journal of Commerce and Social Science. Vol 13 (2): 311-333.

Wann-Yih, Wu dan S. Htaik. 2011. "The Impacts of Perceived Organizational Support, Job Satisfaction, and Organizational Commitment on Job Performance in Hotel Industry". Disajikan dalam International DSI and the 16th APDSI Joint Meeting, Taipei, Taiwan, 12 - 16 Juli

Wheelen, T. L., dan Hunger, J. D. (2013). Strategic Management and Business Policy: Toward Global Sustainability. New Jersey: Pearson. 